early man. In this he was helped and backed up by the late Sir Ray Lankester, without whose aid even Reid Moir might have failed to 'get his ideas over'. The age of the gravels in question has never been doubted. They contain a rich fauna and belong to a period antedating the Cromer Forest bed : in the still current nomenclature they are late Pliocene in date. Moir claimed that in situ in these gravels he had found artefacts, that is, flints which had been chipped by man, and which for reasons given could not have been the result of natural operations.

The heat of the controversy which at once burst on Moir's head can only be explained if we remember that theological as well as archæological considerations were involved. The theory of evolution as outlined by Darwin had, it is true, been somewhat grudgingly accepted by the Churches; but here was a little business man in a provincial town who ventured to throw back the antiquity of man to some incredible date, to throw completely out of balance the accepted order of man's history. On no other ground can one explain the fury of the conflict. One of Moir's opponents actually had printed in colour a Christmas card burlesquing the whole theory. But Moir was of Scottish origin and had been hardly brought up by his father, the founder of the tailoring business he was later to inherit. Indeed, he once told me that at first he was made to sweep out the premises in the morning. He just persisted in his theories, collected more and more evidence from the pits, and studied more and more closely the com. plicated phenomena of flint fracture. Through thick and thin he continued to have the support of Lankester and a small number of scientific men with open minds.

But it was not until 1920 that the great moment came. It must be remembered that prehistory was recognized as a definite subject much earlier on the Continent-more especially in France-than in Great Britain. The two chief exponents there were Profs. Boule and Breuil. Both had written long articles against Moir's ideas. One based his objections on observations of a mortar-making machine at Mantes, the other on some finds of flints flaked as a result of earth pressure. It was in 1920 that Moir discovered certain chipped flints which seemed to him conclusive, and he sent them to the Sedgwick Museum at Cambridge for consideration. The late Prof. J. Marr called me in for consultation and as a result $I$ invited the Abbé Breuil to come to Cambridge at once, which he did. I took him over to Ipswich, and a long afternoon was spent poring over the finds spread out over the floor of Moir's study. Breuil said little, and when driving back in the evening he was still more silent. Then he quietly remarked, "Mon cher ami, aujourd'hui a beaucoup vieilli l'humanité". It was a magic moment! In the following year he announced his change of ideas at an international congress held at Liège. That each and all of the specimens Moir claimed as humanly fashioned were really artefacts may be doubted : that tool-making animals, almost certainly therefore primitive humans, existed at that remote period is, however, a fact accepted to-day by the vast majority of prehistorians. This is Moir's great work, for which he was eventually awarded a fellowship of the Royal Society.

It would take too long to describe in detail all the investigations Reid Moir undertook in the Ipswich district and elsewhere. Some proved to be important and the results were accepted by the scientific world ; others proved less so, and the explanations put for- ward at the time had later to be modified. But this is true for any active investigator in the field. Moir was generous with the specimens found in the course of his excavations, and these are now widely distributed in the museums of England and France; but his first loyalty was to the well-known Ipswich Museum, of which he was the godfather, having, in fact, made it what it is to-day. At the time of his death, he had been studying certain finds made long ago in the Puy Courny district of France. It is to be hoped that his notes are extant. The drawings were already made some considerable time ago; but the War stopped all idea of publication on a scale necessary for such a work.

Moir was interested in many things besides prehistory, and I have letters of his philosophizing on life generally. He had a soft heart and was much concerned that the slaughter of animals for food should be painless. Indeed, he inaugurated a local campaign to this end. To gain time for his many scientific commitments and interests, he turned his business into a company and as such it did not prosper too well. In fact Moir, in the latter part of his life, was an exceedingly poor man as a result of his scientific toil. He was interested in water geology and took this matter up professionally to some extent. As was to be expected, Moir in his younger days in the heat of controversy could be fierce. I have had letters from him which I promptly burnt ! Nevertheless, his characteristic and ferocious brand of language was part of his robust personality, which never shirked a challenge, and indeed helped to endear him to many of us. But there was a lovable strain right through him, and this, together with his charm of manner, in later years took a more and more prominent place in his nature. I can only add that personally I had a real affection for Reid Moir and sincere regrets that he has gone. This emotion, I am convinced, will be shared by everyone who knew him well.

Miles C. BuRKITt.

\section{Dr. L. H. Baekeland}

Is the passing of Dr. Leo H. Baekeland on February 23 in his eighty-first year, the world of applied science has lost an outstanding man. $\mathrm{He}$ was an individual of outstanding character with a high moral status and charming personality. One never tired of hearing his stories of his adventures connected with his travels to most lands and his yachting experiences. He lived to see and to gain the benefit of his two great developments, namely, 'Velox' gaslight paper and 'Bakelite' synthetic resins. Of late years he had been in failing health, and the chemical and technical societies of the United States and Great Britain have missed his presence at their annual meetings for about eight years.

Baekeland was born in Ghent on November 14, 1863. He studied science in the University of his birthplace, making chemistry his chief subject, and afterwards became a lecturer in the University. In 1884 he graduated as a doctor of science at the University of Ghent. Although he was not yet twenty years of age he became professor and taught chemistry at the University from 1882 until 1889, and during 1885-89 he taught both chemistry and physics at the State College of Science, Bruges. During this period he also went to Germany, meeting German men of science and learning their language.

$\mathrm{He}$ married Miss Celine Swarts, the daughter of 
his professor of chemistry, in 1889, and at the end of the same year he emigrated to the United States of America.

In the United States Baekeland devoted the earlier part of his career to research work which resulted in his discovering a process for the production of photographic printing paper, suitable for use in artificial light. To these papers he gave the name 'Velox', which printing paper is still well known throughout the world. In 1893 he founded the Nepera Chemical Co., and in 1898 he sold his interest to the Eastman Kodak Co.

Afterwards, at the age of thirty-five, he returned to research work in a laboratory in a house at Yonkers, near New York, where he worked on various chemical problems, including those connected with resinous products, and made a study of the reaction between phenol and formaldehyde. In 1907 his United States patent on the process for producing phenolformaldehyde resins under control was filed, and this patent became world-famous. In 1909 he read a paper on "The Synthesis, Constitution and Uses of Bakelite" before the New York Section of the American Chemical Society, in which he described in considerable detail the researches which led up to this patent.

In 1910 the Bakelite Gesellschaft was founded in Germany; six months later the General Bakelite Company of America was founded, both companies being for the large-scale production of phenolic resinous materials, known as 'Bakelite' materials. The latter company with the Redmanol Chemical Products Co. and the Condensite Co. of America was afterwards merged into the Bakelite Corporation, of which Dr. Baekeland was the president in 1922.

It was due to Dr. Baekeland's fine personality, initiative and far-sightedness that Bakelite Ltd. in England was formed by an amalgamation of interests which were active in the synthetic resin field.

Many honours were bestowed upon him. He was a commander of the Belgian Order of Leopold, an officer of the Order of the Belgian Crown and an officer of the Order of the French Legion of Honour. For many years he was president of the American
Chemical Society. The W. H. Nichols Medal was presented to him in 1909 ; in 1910 he received the John Scott Medal of the Franklin Institute, and in 1913 he received the Willard Gibbs Medal. When be belonged to the Instruction Board of the Columbia University, he was presented by that University with the Chandler Medal. He was an active member of the Society of Chemical Industry, which in 1916 presented him with the William Perkin Medal of the New York Section of the Society of Chemical Indus. try. In 1915 he was made a doctor of chemistry honoris causa of the University of Pittsburgh. He was also president of the American Institute of Chemical Engineers and of the American Electrochemical Society. In 1938 he was presented with the Messel Medal of the Society of Chemical Industry.

Dr. Baekeland was a member of the U.S. Naval Consulting Board since 1915, a member of the U.S. Nitrate Supply Commission in 1917, and chairman of the Committee on Patents of the National Research Council. He was also a trustee of the Institute of International Education since 1919, and a member of the Advisory Board of the Chemical Division of the U.S. Department of Commerce since 1925.

WE regret to announce the following deaths :

Sir Colin Fraser, director of materials supply of the Australian Department of Munitions and chair. man of the Commonwealth Minerals Committee, and a past president of the Australian Institute of Mining and Metallurgy, on March 10, aged sixty-eight.

Prof. A. E. Jolliffe, emeritus professor of mathematics in the University of London. King's College, on March 17, aged seventy-three.

Dr. A. W. Pollard, formerly keeper of printed books in the British Museum and honorary secretary of the Ribliographical Society, on March 8, aged eightyfour.

Sir David Prain, C.M.G., C.I.E., F.R.S., lately director of the Royal Botanic Gardens, Kew, on March 16, aged eighty-six.

\section{NEW FELLOWS OF THE ROYAL SOCIETY}

The following were elected fellows of the Royal Society on March 16 :

BRIGADIER R.A. BAGNOLD, explorer ; distinguished for scientific work on desert topography, and in particular for his precise studies of the physical principles governing the movements and deposition of sand under the action of wind.

Mr. R. P. BeLr, fellow of Balliol College, Oxford ; distinguished for his theoretical and practical contributions to physical chemistry, particularly the studies of reaction rates in solutions, and the applications of wave-mechanics.

DR. C. R. BuRCH, research physicist, University of Bristol ; distinguished for original research in many branches of applied physics, particularly on the methods for attaining high vacua.

Pror. Subramanya Chandrasekhar, associate professor in the University of Chicago, formerly fellow of Trinity College, Cambridge; distinguished for his contributions to theoretical astronomy and astrophysics, particularly relating to stellar structure and the dynamics of stellar systems.
Mr. G. E. R. Deacon, member of the scientific staff of the "Discovery" Committee of the Colonial Office ; distinguished for outstanding work, particularly in the Southern oceans, on physical oceanography and marine zoology, and the relations between them.

Sir JACK Drummond, professor of biochemistry, University College, London, and chief scientific adviser to the Ministry of Food, distinguished for his work on practical nutrition.

DR. A. T. GLENNY, immunologist, Wellcome Physiological Research Laboratories, Beckenham, distinguished for his work on immunity and its application to the immunization of man and animals, especially against diphtheria and tetanus.

DR. R. G. Hatton, director of the Fruit Research Station, East Malling; the pioneer of scientific pomology in Great Britain ; the research work which he has organized and directed in this field has a world-wide reputation.

Prof. R. D. Haworth, professor of chemistry, University of Sheffield; his contributions to the 